\title{
Strategies for Consulting with the Community: The cases of four large-scale genetic databases
}

\author{
B. Godard, ${ }^{\text {i, ii }}$ J. Marshall, ii, iii C. Laberge ${ }^{\mathrm{iv}}$ and B.M. Knoppers ${ }^{\mathrm{ii}}$ \\ i. University of Montreal, Faculty of Medicine, Bioethics Programs; ii. University of Montreal, \\ Faculty of Law, Research Centre for Public Law; iii. McGill University, Faculty of Medicine, \\ Biomedical Ethics Unit; iv. Laval University, Faculty of Medicine
}

Keywords: genetic database, community consultation, population genetics

\begin{abstract}
Large-scale genetic databases are being developed in several countries around the world. However, these databases depend on public participation and acquiescence. In the past, information campaigns have been waged and little attention has been paid to dialogue. Nowadays, it is important to include the public in the development of scientific research and to encourage a free, open and useful dialogue among those involved.

This paper is a review of community consultation strategies as part of four proposed large-scale genetic databases in Iceland, Estonia, United Kingdom and Quebec. The Iceland Health Sector Database and Estonian Genome Project have followed a "communication approach" in order to address public concerns, whereas, UK Biobank and Quebec CARTaGENE have chosen a "partnership approach" to involve the public in decision-making processes.

Following a comparison of community consultation strategies, the main concerns of the public are examined as well as the challenges of involving communities. Importantly, reported across all groups is the concern for confidentiality, respect of the individual, transparency, and the donor's right to access to their own result. However, even if researchers demonstrate a willingness to respect values such as fair representation, transparency and accountability, there is still a risk that the public will mistrust researchers and simply will not participate in sufficient numbers. Complications may arise when individual and community interests conflicts. The implementation of a partnership approach is definitely involving and costly; however, if used properly, this method can improve both participation and so database development.
\end{abstract}

Address for correspondence: Beatrice Godard, Centre de recherche en droit public, Universite de Montreal, C.P. 6128, Succ. Centre Ville, Montreal QC, CANADA H3C 3J7; email: Beatrice.godard@umontreal.ca.

Paper received, 20 February 2003; Revised: 30 January 2004; Accepted: 11 June 2004

1353-3452 @ 2004 Opragen Publications, POB 54, Guildford GU1 2YF, UK. http://www.opragen.co.uk

Science and Engineering Ethics, Volume 10, Issue 3, 2004 


\section{Introduction}

Recent activity in genomics is spurring interest in the development of databanks. Large-scale genetic databases are currently being developed in several countries around the world. These databanks have been established with the aim of improving genetic epidemiological knowledge of common, complex diseases and of using this knowledge in the field of public health. Such endeavours are precedent-setting on several accounts. Large groups of selected individuals, varying in size from project to project, will be asked to volunteer DNA/blood samples for genetic analysis. The information will subsequently be used for medical research purposes in both public and private laboratories. The DNA samples will be linked to genealogical and personal health information in order to study the genetic as well as the environmental determinants of disease manifestation. Complex diseases have hitherto defied a simple genetic classification and are known to have important environmental factors as part of their aetiology. It is believed that by their scale, format and scope, these genomic databases will lead to clinically useful results and help medical research in a large number of diseases. ${ }^{1}$ But these efforts could also produce misinformation, or lead to misuse by organizations that might discriminate against people possessing what are perceived as less-than-optimal genetic profiles. These databases therefore represent a novel, highrisk initiative that has the potential to produce breakthrough advances in genomics. In fact, these databases differ from the genetic registers of the past as well as from the gene-hunting research of today both because they are based on the general population, as opposed to particular patient groups or families, and because there is a great deal of information gathered about each individual, as well as information about the disease studied.

Another change in the genomics research paradigm is the desire for public consultation. The controversies surrounding the first large-scale genetic database in Iceland emphasized the need for consultation at the outset of project development. In the past, the research community has taken a paternalistic "communication approach" when dealing with public concerns. However, some of the major population genetic projects that have arisen subsequent to the creation of the Icelandic database have taken a "partnership approach." Consultations for public health research initiatives have usually addressed the concerns of academics, researchers, health care professionals, and/or special interest groups. Due to the scale of the contemporary public genetic databases, the consultations must include a large contingent of the general public and, importantly, in order for these projects to begin, it is necessary to have the general public's acceptance. This need and desire for collaboration between academia and the broader public is unprecedented in general science endeavours, although it has been frequently used within the environmental science arena. These consultations are purported to be for the public's benefit, not simply to solicit support. Thus, it is crucial that they be carried out in an unbiased, ethically sensitive way.

A free, open and useful dialogue is encouraged, though it is not effortless to achieve. Yet, when dialogue is the method of consultation, the goal is to provide a forum for identifying and discussing issues, not necessarily for agreement or 
consensus. The National Institutes of Health (NIH) defines community consultation as "a vehicle to listen to the community's interests and concerns, to address ethical issues, and to communicate information about the research to the community." It is important to keep in mind that community consultations are a consultative process, not a vote or referendum. ${ }^{3}$ In community consultation, the sponsors retain authority but consult with the public to obtain input that may influence and improve the decision-making process. ${ }^{4}$

In fact, community consultation may help to identify pitfalls in the design or study plan. This may improve the project's efforts to address issues of importance to the community and to yield meaningful data while working within distinct social and cultural contexts. As the NIH has indicated, community consultation may achieve goals not attainable through individual informed consent and standard ethics review:

"Community members benefit from learning about the study and by understanding the scientific questions it seeks to answer, improving public scientific literacy. Also, members benefit by sharing results with a community after a study has been completed, research participants are more likely to know what to do to seek treatment or how to implement preventive measures to improve their health. Community consultation is also intended to elicit feedback regarding potential participants' relevant values, preferences, concerns or judgments. As partners in, rather than simply as subjects of, the research activity, consultation increases the likelihood that community members will feel empowered rather than exploited."2

This paper examines the community consultation strategies component of four proposed large-scale genetic databases in Iceland, Estonia, the United Kingdom (UK) and Quebec. After a brief overview of the four genetic databases (I), their community consultation strategies are compared (II), and the main concerns of the public are examined (III), as well as the challenges of involving communities (IV). The paper concludes with some examples of the best ways to carry out community consultation.

\section{I: Overview}

The Icelandic Health Sector Database, Estonian Genome Project, UK Biobank and Quebec CARTaGENE are all at different stages of development (Table 1, pp. 474475). The Icelandic Health Sector Database was assembled with initial approval from the Icelandic government in 1998 and with funding from a private company called deCODE Genetics. However, the database resource has yet to become fully operational. $^{5}$ In 2001, the non-profit Estonian Genome Project Foundation was founded to oversee the establishment of the database with funding primarily from the Estonian government and international private investments. ${ }^{5}$ A pilot project to test the overall plan was initiated October 2002 and expanded to all of Estonia during 2003. In June 2002, the Wellcome Trust, Medical Research Council (MRC) and the UK Department of Health committed $£ 25$ million to UK Biobank. ${ }^{6}$ Pilot studies for their population genomics study began in early 2003. Finally, the Quebec CARTaGENE project, primarily funded for its "proof of concept" phase by the Réseau de Médecine 
Génétique Appliquée (RMGA) of the Quebec Health Research Fund (FRSQ), is currently receiving approval and pilot funding from Genome Quebec and the Health Ministry (MSSS) of the Quebec government.

\section{Aims}

All of these large-scale genetic databanks have been established in order to find genes associated with common diseases. All of the databases will link lifestyle and personal health information to genotypes for use in scientific and public health research. The Icelandic and Estonian databanks will gather genetic information from a relatively homogeneous population whereas the Quebec and UK databanks will be examining genetic variation in large, heterogeneous populations.

\section{Size}

One aspect of these genetic databases that sets them apart from other types of previously developed databases is their size. The smallest of these is Quebec CARTaGENE which will include $1.5 \%$ of the province's population, or $60-65,000$ individuals. The Icelandic database, next in size, theoretically could include about 270,000 individuals; this number represents the entire population of the country and includes children as well as the deceased. The UK Biobank will consist of 500,000 randomly selected adults and the largest will be the Estonian database which will include the entire population, that is, one million individuals. The large target number for each DNA bank is due to the nature of the intended research. Since the main focus of the databases is the genetics of complex diseases, the investigators involved are concerned with identifying important genotypes, environmental exposure and outcome interactions. A reliable quantification of these interactions requires large populationbased studies that correlate DNA variants across the genome with lifestyle information and the development of particular diseases. ${ }^{7}$

\section{Public resource}

All of the databases are public research resources. Only the Icelandic Health Sector Database has granted an exclusive license to a private company, deCODE Genetics, with access provided to the Icelandic Ministry of Health and by commercial subscription from other companies. ${ }^{8}$ While the Estonian Genome Project intends no exclusivity of access for public institutions, with regards to pharmaceutical and biotechnology companies, non-exclusive license agreements will be granted through their for-profit subsidiary, EGeen. ${ }^{9}$ The UK and Quebec DNA banks do not intend to have any exclusivity of access for any public or private laboratory. The only restrictions would be based on scientific and institutional review board (IRB) decisions.

\section{Consent, access to data and legislation}

Regarding the three topics of consent, access to data and legislation, the projects differ to varying degrees. All of the projects require informed consent in writing for all data and samples, except Iceland. The early controversy surrounding the Icelandic Health 
Sector Database dealt with the issue of consent. The "volunteer's" medical records and genealogical information are on the health database without consent. Icelanders must opt-out and be placed on an abstainers list in order to be excluded from entry into the database. ${ }^{8}$ This is seen by many to be a very weak form of consent especially since this option is not open to children and individuals with impaired competence. ${ }^{10}$ In Iceland, once consent is presumed, no additional consent is required for any subsequent use of the individual's samples ("blanket" consent) obtained during medical care. Sampling specific to genetics research projects requires an explicit consent.

In the case of the UK database, participants in the project will be consenting to "participate in UK Biobank," and this consent will cover any project for which the data is subsequently used. ${ }^{11}$ Volunteers participating in the Quebec CARTaGENE project will give a general consent with additional consent for multi-layered options. A general consent will allow the anonymized use of data and biological materials; however, in order to provide benefits to participants from the semi-longitudinal approach, participants will be offered a variety of different choices. ${ }^{12}$ The Estonian project will require written informed consent for each use of a participant's linked personal information (gene donor consent form). ${ }^{13}$ Children over the age of seven will be asked to participate in the Estonian Genome Project, with consent from their parents.

If volunteers wish to withdraw from the database, or if they need to be recontacted for research and/or consent purposes, their personal information in the databank will need to remain coded and, therefore, cannot be completely anonymized. Under these circumstances, protection of donor confidentiality is usually addressed through the establishment of an independent body that controls the decoding of samples and the distribution of information to authorized researchers. Thus, the Quebec CARTaGENE project will be double-coded by the Quebec Health Insurance Board (RAMQ) and by CARTaGENE. The UK Biobank literature notes that the personal information of volunteers will be in a "reversibly anonymized" format. This format allows those with authorization to re-link the volunteer's identifying information with the data and DNA samples via a code. The Icelandic database will contain anonymized information through unidirectional encryption, with no possibility of recontact, whereas, the Estonian database protocol states that the participants' data will be coded only.

The UK Biobank project makes clear in its literature that, while the participant's data will be traceable to them, they will not have access to any of their own personal genetic or other research results. Essentially, the same situation exists in Iceland and Quebec. The Estonian Genome Project is the only project that explicitly states that donors upon request will have access to their personal data and research results. The other projects state that information will be available only at the general population level via normal peer-review processes in scientific journals or via press releases and will not be provided to the volunteers directly.

No specific legislation governs the databanks in the UK and in Quebec. UK Biobank is covered by the Data Protection Act 1998 and the Human Rights Act 1998 and common law. CARTaGENE is covered by the Quebec Civil Code and by Personal Information Access Legislation. In addition, the UK MRC has drafted guidelines on the use of biological samples and personal medical information. ${ }^{14}$ In Quebec the 
RMGA drew up in 2000 a Statement of Principles on Human Genome Research ${ }^{15}$ as concerns individual/familial sampling which, in 2003, was followed by a Statement of Principles on the Ethical Conduct of Human Genetic Research in Populations ${ }^{16}$ and the Commission on Ethics in Science and Technology expressed an opinion on ethical issues raised by genetic databases for a responsible and democratic framework. ${ }^{17}$ The approach taken by the UK and Quebec reflects a preference to utilise existing legislation to govern large-scale databases and an historical tendency toward selfregulation of medical research with minimal reliance on parliament. In contrast, Iceland and Estonia have taken the legislative approach by passing the Health Sector Database Act 1998 and the Human Genes Research Act 2000, respectively. The Icelandic Act for the Health Sector Database allows the Minister of Health, to grant a license to a private company for construction of an electronic database containing selected and coded data from the country's health records. This Act also gives the company the right to exploit the data for commercial purposes. The Estonian Genome Project's web page provides a different rationale for the establishment of the Human Genes Research Act. The objectives listed are: to regulate the maintenance of the database, to ensure the voluntary nature of gene donation, to ensure confidentiality of the identity of the gene donors and to protect individuals from the misuse of genetic data and discrimination (link to Human Genes Research Act). ${ }^{13}$

\section{II: Comparison of Community Consultation Strategies}

Community consultation is an increasingly common adjunct to genetics research, particularly for projects aiming to create large-scale genetic databases for use by multiple researchers, with numerous protocols, over an extended time period. Many factors motivate investigators to engage communities although it is not legally required. Due to the scale of these databases, the risk of group harm gives greater urgency to ensuring that communities understand the project, and to seeking their input regarding how the project and the groups are described. A process of ongoing dialogue facilitates greater comprehension and elicits a response to the potential concerns of participants.

Regarding the four community consultation strategies examined, they vary among the four countries; however, they can be divided roughly into two types. Iceland and Estonia follow a communication type of approach using quantitative rather than qualitative measurements of public opinion. The UK and Quebec favor a public participation or partnership approach where analysis of public opinion is both quantitative and qualitative.

\section{Iceland}

In Iceland, cursory formal public discussion took place prior to the establishment of the Health Sector Database. The discussion consisted of 100 radio and TV programs and several town meetings across Iceland. After the programs and meetings had taken place, a survey indicated $75 \%$ support for the act and $25 \%$ against. ${ }^{18}$ In April 2000, a later poll showed $90 \%$ support for the database. However, this latter poll is considered 
by some in Iceland to be unrepresentative. Petur Hauksson of Mannvernd (the Association of Icelanders for Ethics in Science and Medicine )stated that deCODE used misleading information in the poll, appealing to Icelanders to contribute to the global fight against disease, in the hope of recruiting support for their database. ${ }^{19,20}$

A Data Protection Commission and Research Ethics Committee have been founded by the Icelandic government in order to address contentious issues, such as, access to genetic information by individuals and third parties and the exclusive license given to deCODE Genetics. Information about the database is freely available on the internet and the company deCODE has a web page sporting news releases, research initiatives and financial information. ${ }^{21}$ Alternatively, an international web forum has been established by the University of California at Berkeley and the University of Iceland. ${ }^{22}$ Despite the attempts to not only provide information to the population via the media and the internet, but also to provide some modicum of debate, there still exists organised opposition in Iceland. The most vocal opposition is from "Mannvernd". Whether this dispute is due to the legislation of a database act per se, or is a dispute over particular aspects of the Act, or both, is not clear. However, group members argue that the Act infringes on human rights. There are also concerns that a private company has a license to collect genetic, medical and genealogical information from the Icelandic population. Additionally, the Mannvernd web site has reported that as of June 2003,20426 individuals have chosen to opt out of the database, that is, over $10 \%$ of the Icelandic population. ${ }^{19}$

\section{Estonia}

The case of Estonia is somewhat different from Iceland although their approach to community consultation is similar. Although there has not been extensive public debate in Estonia beyond opinion polls, the country boasts a higher level of acceptance than seen in Iceland. Only $6 \%$ of the Estonian population are against the establishment of the database. The Estonian Genome Foundation has been careful to address issues of consent, confidentiality, trust, and discrimination. The Icelandic government and deCODE genetics have historically not been as attentive to these ethical concerns. This could explain the somewhat greater degree of acceptance in Estonia as opposed to Iceland. Also, there could be a sense that the Icelandic project, with its exclusive licence to a private company, is profit-driven and, comparatively, the Estonian project is geared toward public health since it is being provided as a public research resource.

The Estonian Genome Project's communication strategies tend toward the provision of scientific fact rather than open discussion of ethical and policy issues. The public in both Iceland and Estonia has not been provided a forum in which to discuss their concerns or to influence the direction of project development. Public opinion in these countries relies on Gallup poll results.

The Estonian Genome Project's web sites ${ }^{9,13}$ provide access to more information than the deCODE site. It is possible to view information on the Human Genes Research

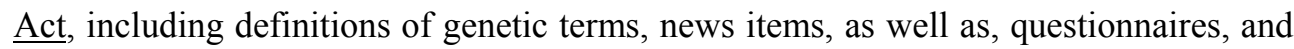
the results of current Gallup polls. Their web page states that the Estonian Genome Project aims to provide to all members of the Estonian population (whether a 
participant in the project or not) general knowledge of genetics, either through the media or directly from a doctor. Also, all information connected with the establishment and functioning of the gene bank is to be made public.

\section{United Kingdom}

The project overseers involved with UK Biobank and CARTaGENE will carry out all of their community consultations using a partnership or collaborative approach. The model chosen by the UK and Quebec aims to address contentious issues through direct collaboration with the public. Attention will be focused on the proposed goal, i.e., efforts on behalf of the public so that the process will not be perceived to be used solely to provide a green light for researchers.

The UK has already carried out several in-depth community consultations that address, either directly or indirectly, issues associated with the establishment of genetic databases. The consultations consist of focus groups, of various sizes, comprised of members of the general public and stakeholders (mostly doctors and nurses). Two early series of focus groups carried out in the spring of 2000, were designed to assess public attitudes toward scientific communication and genetic information, and were commissioned directly by the Welcome Trust (WT) and the MRC. ${ }^{23,24}$ A third set of focus groups initiated in the autumn of 2000, called "Public perceptions of human biological samples," was directly related to UK Biobank and was carried out by a market research group. ${ }^{25}$ This first phase of community consultation was designed to inform policy-making, regarding which safeguards would be most acceptable to the public when establishing the large population cohort, and also to assess the likely public response to the proposed study. ${ }^{26}$ The researchers found that genetics was positively viewed when it was coupled to prevention and identification of genetic predisposition to disease. As a result of this third set of focus groups, the WT and the MRC were encouraged to focus on these positive associations so as to engender more support from the public, although some might construe this as manipulative.

The latest Biobank consultation report, "UK Biobank: A question of trust" was published in March, 2002. ${ }^{27}$ This series of focus groups, funded by the MRC and the WT and carried out by an independent science policy consultancy, People, Science \& Policy Limited (PSP), was composed of a variety of sessions: three sessions each involved 20 people aged 45 to 69 (the proposed age of volunteers for UK Biobank). In following sessions these groups of 20 were split into two smaller groups of 10 for an introductory meeting of 1.5 hours. The groups were then reconvened for a four-hour interactive workshop with PSP moderators and two members of the project team, one from the WT and the other from the MRC. This particular interactive discussion was carried out in order to explore and address questions about ethical and management issues surrounding the proposed UK Biobank project. Issues identified by the participants include recruitment, confidentiality, the governance of Biobank, "value for money", data usage, thoughts on the name "UK Biobank", and the need or not for further consultations. Additionally, an Ethics Consultation Workshop was carried out by the WT and MRC in the spring of $2002{ }^{28}$ Attitudes towards consent, confidentiality, security of data, commercialization and governance were solicited from 
60 senior representatives of the biomedical sciences, clinical medicine, social science, ethics and the law.

Despite these consultations, in the UK there is some organised opposition to the establishment of the UK Biobank. Critics claim that the British government is pushing ahead without a proper independent review of the validity of the science or safeguards for the public. ${ }^{29}$ GeneWatch UK, also questions the scientific validity of the database and is calling for a review of the project, independent of the MRC and WT. ${ }^{30}$ Additionally, GeneWatch UK is concerned about the relationship between commercial interests and the databank and about the use of a general form of consent. ${ }^{11}$ Another group called the Human Genetics Alert believes the establishment of the database is premature because the ethical issues and purposes of UK Biobank have not been fully addressed by parliament or reviewed by the public. ${ }^{31}$ The Institute of Science in Society, located in London, criticizes the MRC and WT community consultation as being biased. It claims that many public concerns raised during the focus groups and interactive discussions are not being adequately addressed. ${ }^{32}$

\section{Quebec}

The consultation strategy of Quebec's CARTaGENE project is at an earlier stage than the UK Biobank. Consultation is being carried out by two independant market research organisations. The target audience is the general public; the geographic area of influence is the province of Quebec, divided into 18 regions. Community consultation consists of three parts. The first, "Social Perceptions Research Platform," was carried out during Autumn 2003 and contained a qualitative and quantitative phase. The purpose of the qualitative phase was to identify the social and ethical concerns of the public regarding the establishment of a large-scale genetic database. It consisted of 19 focus groups of 7-8 individuals chosen randomly out of the phone book throughout Quebec's population within four regions. Groups were distributed according to qualitative representative criteria: demographic, economic, linguistic, cultural and regional diversity. Four aspects were measured: perceptions and knowledge of genetics; enthusiasm for or fears about CARTaGENE; evaluation and understanding of communication tools; and deterrents and incentives to participating in CARTaGENE. Results indicate that the CARTaGENE Project is perceived to hold promise for all of society; to represent an important event with concrete spin-offs for society; and to be important for the future in terms of prevention and treatment of disease, and, therefore to have a of positive impact on the healthcare system. Nevertheless, individuals across all groups worried about confidentiality, transparency, and the right to access to their own result. Consequently, participation in the CARTaGENE Project would depend on a response to these concerns.

The quantitative phase of Part I aimed to validate the results of the focus groups. This phase also aimed to evaluate public perceptions and attitudes towards the CARTaGENE Project and its communication strategy. A phone survey was conducted in all 18 regions. Among 1800 individuals, 76.9\% agreed to participate in the survey. The same four aspects examined in the focus groups were measured. Results show that 94\% of respondents considered the CARTaGENE Project important for the Quebec 
population. However, $19 \%$ of respondents thought that this Project was of little or no importance for them. In other respects, $80 \%$ of respondents showed enthusiasm for the Project. Finally, $19 \%$ of respondents considered that they would participate while $25 \%$ thought that they would probably not participate, especially among people not having completed grade 6 . The probability of participating in CARTaGENE increased under various conditions: convenience of physical exam and blood sample (distance from personal residence), potential loss of time and income, disclosure of personal results to them, guaranteed confidentiality. Finally, $85 \%$ of respondents were in favor of a recall if CARTaGENE researchers needed it.

Part two of the plan for community consultation includes several different methods that have been, or will be, implemented in Quebec. In June 2001 and June 2003, two workshops on the CARTaGENE Project and its ethical and legal aspects brought together professionals in ethics, law, decision and policy-making. Other techniques have been implemented to inform and involve citizens prior to and during the Project: web site access, newsletter publications, press releases and a toll-free hotline. Specifically, before the recruitment of Project participants starts, posters and information leaflets will be widely distributed, and during recruitment, information sessions will be organised (including all regions, indigenous peoples and ethno-cultural communities) to address/respond to questions raised by the population. The rationale for the different types of consultation is to promote an understanding of the science behind CARTaGENE and to engage the Quebec population in a constructive dialogue about the relationship between science and society. The web page is presently in operation, giving access to newsletters, press releases, and other documents. ${ }^{33}$

Part three of the community consultation plan consists of a deliberative electronic forum. The motive for this process of community involvement is to provide a greater consideration of public opinion. As stated in the CARTaGENE research proposal, the public's point of view cannot be achieved through information sessions only. A partnership approach requires consultations favoring exchanges between researchers and citizens to ensure that all opinions and views are taken into account. The deliberative web forum will ensure a continuing discussion and presentation of the public's point of view. Any information gleaned from the electronic forum will be published.

\section{III: Concerns of the Public}

The community consultation attempts of the UK have been the most extensive and will provide invaluable information for other groups. In the case of Iceland, the deCODE web page does not provide any information about the views of the Icelandic population, however, the opposition group, Mannvernd, does post particular concerns. Estonian public opinion is hard to gauge due to the fact that there has been minimal debate in that country. Yet as in Iceland, a law was adopted in a democratic parliament. Finally, the Quebec CARTaGENE project has carried out the first phase of its community consultation. This first phase draws a picture of the socio-cultural perceptions and intents of the Quebec population. 
It is apparent, after the perusal of the references mentioned above, that particular public concerns are repeatedly mentioned. ${ }^{8,14,19-20,22,32}$ A synopsis was compiled of the main public concerns using information from the web pages of deCODE Genetics, Mannvernd and the Estonian Genome Project, the reports of the UK consultations, and the phase I results of the CARTaGENE consultation.. In general, it is believed that scientific research is admirable. Projects such as these large-scale genetic databases are seen to hold promise for the greater population. Importantly, however, reported across all groups, is the concern for confidentiality, respect of the individual, transparency, and the donor's right to access to their own research result.

\section{Confidentiality and respect for the individual}

It appears that, in general, individuals are attracted by the idea of donation for the "greater good" but want to be assured that they will benefit from this donation and that their individuality will be respected. Not surprisingly, there is considerable concern about how employers or insurance companies might use human genetic information. Many fear that if others have access to their genetic information they will know too much about them. Genetics can be a very useful diagnostic tool but in most cases the diagnosis of disease, disability or condition depends on probabilities. It is not clear how accurate genetics will be as an indicator of individual health or disease. Irrespective of the probabilistic nature of such genetic information, the public needs reassurance that any results of research using genetic database information will be handled in a responsible way and that their best interests will be represented.

\section{Transparency}

Issues surrounding transparency were strongly voiced in the UK and Quebec, especially with regard to informed consent. Those in charge need to communicate why the sample collection is being set up, how the samples will be used, and to obtain consent for access to medical records. In keeping with the principle of transparency, it will be necessary to make clear to donors that their samples could be used in ways that are not currently known, following ethics review, especially when providing blanket consent.

\section{Access to research results}

Many members of the public expect that the results of research or tests will provide donors with a cornucopia of personal information and consider this a potential motivator for participation. In Quebec particularly, the response of participants of focus groups indicated that donors would be willing to forgo anonymization in favor of coding in order to gain access to personal test and research results. In addition, as noted in "UK Biobank: A question of trust," the limitations of any research or testing must be made very clear. Donors need to know what sort of information will be provided on what sorts of diseases. 


\section{Public resource}

There are also two miscellaneous concerns that were mentioned in one or more of the projects. The Quebec population voiced strong support for public ownership of medical genetic databases and a concern for exclusivity of research resources. In Iceland, the Health Sector Database was founded without much reflection about the protection or consultation of the public. This resulted in a sense that the Icelandic government and the company, deCODE, had little respect for the well-being of the database donors. The founders of the project have had particular difficulty regaining the trust of members of the medical profession. After the establishment of the Icelandic database and the international evaluation of its operations, all subsequent large-scale genetic databases have developed their databases as public research resources paying serious attention to public opinion.

A concern voiced by the public in both the UK and Iceland is the belief that research on human genetics is tampering with nature. They expressed anxiety about the possible misuse of samples via activities such as cloning or eugenics. In the UK, opposition apparently reflects the belief that public consultation was not conducted independently. There seems to be a sense that the WT and MRC were too much involved in the consultation process and they have been accused of "forum shopping". In the UK, opposition groups are suspicious of the validity of the science for which the database is being created. Debate exists within the scientific and medical community as well. This kind of uncertainty about the risks and benefits of population genetics is usually avoided through community consultation. Withholding information, or not directly addressing contentious issues, can lead to mistrust. Opponents of the UK Biobank also complain that public concerns and ethical issues are being ignored in spite of the ethical enquiries undertaken by the funders of the UK Biobank.

\section{IV: Challenges of involving communities}

Historically, public debate and scientific endeavour have existed in separate fields. The development of large-scale genetic databases around the world has played a role in bringing these two fields closer together. Due to the novelty of community consultation in areas of human genetics and the use of genetic information, a careful understanding of public opinion is needed. A shift from the Icelandic model to a more open public discussion and debate has occurred. This shift has culminated in the UK and Quebec community consultations where a variety of methods have been proposed and followed in order to gain a clearer understanding of public opinion. Scientific research is gradually being transformed from an independent and scholarly enterprise into a service for society.

Community consultation is also presented as an avenue for the public to influence the direction of project development. It is thus important that those in charge indicate how public discussions have shaped a project. Unfortunately, the influence and impact of public discussion and debate have rarely been made explicit in any report or webbased forum. For instance, in the report "UK Biobank: a question of trust," 22 recommendations are listed in the conclusion, however, the report does not indicate 
whether any of these recommendations are being seriously examined. It is essential that UK Biobank provide follow-up information. The Human Genome Commission, Office of Science and Technology, and the House of Lords web pages have links to reports in which some recommendations from community consultation have been documented. However, any web-based access to documents is exclusionary since many individuals do not have access to computers. If an opinion is to be politically effective, one needs a considerable degree of commitment and organisation. ${ }^{34}$ In one of the UK consultation reports it was found that there is a lack of a framework within which people can access information about new science. ${ }^{24}$ There is a need for the creation of organisations with different perspectives to encourage a public dialogue. This lack of an experienced public voice makes it difficult to achieve the goals of community consultation.

In Iceland, protests prompted creation of additional database safeguards such as the founding of a Monitoring Committee, Data Protection Commission and an Interdisciplinary Ethics Committee. The role of these regulatory bodies is to ensure that the running of the database conforms to the conditions and regulations of the Health Sector Database Act $1998 .{ }^{8}$ In addition, public debate in Iceland is improving and in late 2001 an agreement was reached between the official representatives of the medical profession, government and deCODE to proceed together for 12 years. ${ }^{5}$

Comparatively, Estonia has been avoiding the problems encountered by Iceland. The country is eager to follow the ethical guidelines set out by the European Union. The Estonian Genome Foundation is becoming increasingly interested in involving the Estonian public. The Foundation has committed more resources to communication efforts through the media and has initiated a debate in the national newspapers on the risks and benefits of personalized medicine. ${ }^{35}$

In the case of Quebec, through a deliberative electronic forum, CARTaGENE researchers, aim to provide an integrated, active and collective partnership approach, whereby the concerns and interests of citizens are taken into account. They also aim for transparency and openness at all levels.

Even if researchers demonstrate a willingness to respect values such as fair representation, transparency and accountability, there is still a risk that the public will mistrust researchers and simply will not participate in sufficient numbers. Other projects involving DNA and data banking have failed because of public concerns: recently, the private company Autogen attempted to set up a genetic database composed of the population of Tonga, an island in the South Pacific. The Tongans opposed the establishment of the database because of concerns about informed consent, and the lack of public discussion. ${ }^{36}$ The project was halted. In the USA, the National Heart, Lung and Blood Institute refused, apparently on communitarian grounds, to allow Boston University to consummate a deal with a private company for the publicly acquired Framingham data. ${ }^{37}$ Disregard for public opinion led to suspicion of the private companies and their motives. Complications may arise when individual and community interests conflict. If the community consents to research participation, individuals may still refuse to participate; but if the community does not consent, then individuals who are identified because they are members of the community should not be approached for study enrolment. Issues of representation, social identity, internal 
politics and cross-cultural differences abound. ${ }^{38}$ Yet, others have written that organized public involvement in priority setting could have a negative impact on research and development. The public could undermine the peer-review process by urging the government to support projects that have not been adequately reviewed or to stop valid research for political reasons. ${ }^{39}$

Communities are cautious and sometimes skeptical about researchers because of scandals. Distrust amongst African-Americans may have been compounded by the shortcomings of the sickle cell screening programmes of the 1970s and more recently the Violence Initiative targeted at inner-city African American and Hispanic youth. ${ }^{40}$ The use of blood samples from native people on Vancouver Island in Canada for undisclosed research projects is another example of reason for distrust. ${ }^{41}$ There are also general concerns that genetics may function to reaffirm perceived biological differences between populations, erect more barriers between groups, and create more avenues for discrimination. ${ }^{40}$ On the other hand, certain communities fear that they will be left out of potentially beneficial research, and they will therefore not be able to gain access to the technologies that result from genetic research. ${ }^{42}$ Yet, as discussed by Burgess and his colleagues, ${ }^{43}$ "population-wide genomics research and its ensuing developments (prevention through better screening and earlier treatment) may offer the most significant chance of benefit for individuals and populations that might otherwise find the health benefits of genome research inaccessible." Protections for communities in genetic research represent another challenge for the research community and public policy-makers on how to enable innovation to occur in a manner which is both ethical and commands broad social and cultural acceptability. ${ }^{44,45}$

The recruitment of thousands of individuals for large-scale genetic databases calls for in-depth knowledge of the socio-cultural perceptions of the projects. Scientific aspects and issues need to be publicly discussed to help individuals in different communities understand the complexity of genetics research and subsequently to improve informed decision-making in these communities. Socio-cultural interests and concerns also need to be discussed to help researchers and policy-makers increase their understanding of the diversity of cultural beliefs and to develop a curriculum addressing culturally sensitive issues. Obtaining a community's point of view cannot be achieved simply through information sessions. ${ }^{46,47}$ As has been mentioned before, aggregated individual opinions are not a sufficient measure of what will happen in the public sphere, due to the intensity of commitment and the degree of organization and resources that genetics research requires. The process of dialogue is a more effective manner by which communities can have their collective voices heard by researchers and policy-makers, and for a number of different reasons. First, as indicated above, representatives of the general public need to be informed on the issues to fully consider all angles before they can voice an informed opinion. Second, these representatives need to come together face-to-face to share and understand those with similar and conflicting interests and concerns in order to gain new perspectives on the potential benefits and dangers of research and technology. ${ }^{43}$ Through thoughtful discussion of the issues, people are able to clarify and verbalize their own values, attitudes and beliefs and examine those of others. They are then able to find alternative approaches 
that are equitable while respecting ethical and cultural pluralism. Of course, the personal preferences of the citizenry may be shaped or influenced by racial or other prejudices. ${ }^{39}$ Inclusion of minority groups and those with disabilities in the deliberation process is therefore an important part of public involvement in the progress of largescale genetic databases.

Taking into account the diversity of interests and concerns that exists between groups will ensure a fair representation of these groups and will certainly facilitate their involvement in genetics research. Since many of these populations have an ethnic or religious identity that might become associated with genetic knowledge or phenotypic predispositions, it could be very helpful to address their concerns as to the equitable distribution of research benefits. For instance, the province of Quebec includes more than 19 cultural communities.

There is evidence that the Canadian public is generally very supportive of genetics research. Yet, knowledge and understanding remain modest. ${ }^{48} \mathrm{~A}$ more thorough study has been done in the UK and it provides a useful starting point. ${ }^{24,25}$ The need for improving social and cultural management of technological development is being increasingly recognized by scientists and policy-makers. Public consultation, community involvement and transparency of decision-making are taking hold in official discourse. As a consequence, in Quebec for instance, genetic databases are high on the policy agenda. The Quebec Commission on Ethics in Science and Technology has provided an opinion on ethical issues raised by genetic databases within a responsible and democratic framework. ${ }^{17}$ The Quebec Network of Applied Genetic Medicine, in its Statement on the Ethical conduct of Genetic Research in Populations, ${ }^{16}$ also recommends that "the values and cultural worldviews of the population should be taken into account at every stage of the research." It should be noted however that researchers are not required to consult the communities. In addition, while Institutional Review Boards (IRBs) often consider the implications of the research project for the community, community consultation is not required in the IRB approval process. There is no agreement on the ethical and policy goals that community consultation can achieve and which methods best address these particular goals. There is little agreement as to what should trigger community consultation, nor the standards by which oversight bodies should evaluate them. ${ }^{49}$

\section{Conclusion}

Recent professional guidelines stress the importance of community consultation and involvement in population genetics research. ${ }^{2,16,17}$ Given the importance of maintaining public trust in biomedical research and the growing concern about privacy, discrimination and stigmatization, it is essential to improve our understanding of cultural attitudes regarding DNA and data banking. ${ }^{27,50}$ From the moment scientists better understand socio-cultural interests and concerns surrounding genetics research, research protocols can be modified to be respectful of cultural customs and to allow a greater involvement with and leadership of the communities themselves. To that end, the community must be involved in the research process through a dialogue between 
researchers and community members. The underlying rationale is that community members are able to identify risks themselves and, often, can develop ways to minimize those risks that outsiders cannot. ${ }^{44}$ Such involvement may also reveal where communities place large-scale genetic databases in their moral, spiritual or religious frameworks, as well as the ways in which the public is grouped. This is important because this information might be decisive for framing the future of genetics research.

Examples from two Native American communities show that community consultation can be effective only if researchers respect the diverse moral and social arrangements of those populations, recognize diverse moral and social harms they could suffer as a result of their participation, and take steps to reduce research-related risks so that both participants and non-participants with a shared social identity are protected. ${ }^{44}$ Also, in a research study on social patterns in African-American and European-American attitudes on genetics, ${ }^{40}$ it has been shown that rapid advances in genetic information may simply occur faster than many people can process. In fact, with relatively little preparation to understand breakthroughs in genetic research, the general public has been given a considerable amount of scientific information on genetics over the last several years. Consequently, many people may not be ready to embrace genetics. It is possible that some of the new knowledge may contradict certain individuals' and groups' ideas regarding the etiologies of disease and other conditions. For others, the genetics revolution may undermine their world views about human nature and social identity. Yet generally, the public accepts genetic technology, uses it, and is excited about the deeper level of understanding of nature that this research affords.

Moreover, in order for community consultation to be effective, steps must be taken to safeguard specific communities from becoming targets of discrimination. ${ }^{45}$ Ethnicized social categories are increasingly highlighted. Researchers have discussed social mechanisms that underscore the use of genetics to maintain existing stratification relationships. $^{51,52}$ When consulting communities, researchers have to address how developments in genetic technology may intersect with existing race and ethnic relations. The social construction of race involves some notion of genetic differences within populations, and fears have been expressed that genetics may function to reaffirm perceived biological differences within populations, increase barriers between groups, and create more avenues for discrimination. ${ }^{40}$ For instance, Furr showed that African-Americans were more likely to view genetics unfavorably when compared to a sample of European-Americans. ${ }^{40}$ These fears and perceptions could not be ignored when consulting with communities.

Finally, consulting communities may be better achieved through a two-way communication between investigators and the community. Initiating a dialogue with the community is needed if we are to find out what people really think, and if we are truly to consider participants as partners. ${ }^{53}$ For instance, the CARTaGENE Project approach, through its different consultation methods, integrates an active and collective conception of citizenship, where preoccupations and interests of citizens are taken into account. CARTaGENE's researchers acknowledge that the establishment of a longterm partnership and the promotion of constructive dialogue necessitate that the public 
be both well-informed and widely consulted. This dialogue and partnership approach, although not fully actualized in population genetics, is in line with efforts to project transparency and open-mindedness at all levels. ${ }^{54,55}$ The partnership approach aims to favor values such as integrity, ethical pluralism, respect for others, and democracy. ${ }^{56,57}$ In addition to facilitating the recruitment and involvement of participants, such an approach can also help to identify and minimize the risks associated with research. Hence, both researchers and participants have a mutual interest to work together as partners with the appropriate balance of input and responsibility from academia and the public. $^{58,59}$

Community consultation does not guarantee prevention of harm. Yet, on the basis of research findings, open discussion creates a forum that allows a considered response from community members to scientific realities and potential outcomes of research. As Robert May ${ }^{\mathrm{a}}$ recommends after reviewing the history of bovine spongiform encephalopathy, "consult widely and get the best people, but also make sure dissenting voices are heard; recognize and admit uncertainty; and above all, be open and publish all advice. Try to separate risk assessment from risk management, and aim at management that is proportional to the risk involved. Wherever possible, make the facts and uncertainties clear and leave it to individuals to choose., ${ }^{, 59}$

Acknowledgment: This work was part of the grant, Genomics in Society: Responsibilities and Rights, funded by Genome Quebec.

a. Sir Robert May is President of the Royal Society (2000-2005). For the five-year period ending September 2000, he was Chief Scientific Adviser to the UK Government and Head of its Office of Science and Technology. 
Table 1: Comparison of four large-scale genetic databases

\begin{tabular}{|c|c|c|c|c|}
\hline & $\begin{array}{c}\text { Iceland: } \\
\text { Icelandic Health } \\
\text { Sector Database }\end{array}$ & $\begin{array}{c}\text { Estonia: } \\
\text { Estonian Genome } \\
\text { Project }\end{array}$ & $\begin{array}{c}\text { UK: } \\
\text { Biobank }\end{array}$ & $\begin{array}{c}\text { QC: } \\
C A R T a G E N E\end{array}$ \\
\hline $\begin{array}{l}\text { Research } \\
\text { focus }\end{array}$ & $\begin{array}{l}\text { - } \text { genetic linkage } \\
\text { analysis } \\
\text { - } \text { association } \\
\text { studies } \\
\text { - genetic } \\
\text { epidemiology } \\
\text { - pharmaco- } \\
\text { genetics } \\
\text { - gene hunting }\end{array}$ & $\begin{array}{l}\text { - public health } \\
\text { - genetic } \\
\text { epidemiology } \\
\text { - pharmaco- } \\
\text { genetics }\end{array}$ & $\begin{array}{l}\text { - } \text { genetic } \\
\text { epidemiology } \\
\text { with specific } \\
\text { attn to diseases } \\
\text { of later life } \\
\text { - public health } \\
\text { - pharmaco- } \\
\text { genetics } \\
\text { - not a gene } \\
\text { hunting project }\end{array}$ & $\begin{array}{l}\text { - } \text { genetic variation } \\
\text { - } \text { association } \\
\text { studies } \\
\text { - } \text { genetic } \\
\text { epidemiology } \\
\text { - public health } \\
\text { - pharmaco- } \\
\text { genetics } \\
\text { - not a gene } \\
\text { hunting project } \\
\end{array}$ \\
\hline Data & $\begin{array}{l}\text { - } \text { personal health } \\
\text { information } \\
\text { linked to } \\
\text { genotypes and } \\
\text { genealogies } \\
\text { - retrospective } \\
\text { - info kept for } \\
\text { approx } 12 \text { years }\end{array}$ & $\begin{array}{l}\text { - personal health } \\
\text { information } \\
\text { linked to } \\
\text { genotypes, } \\
\text { clinical histories } \\
\text { and geneologies } \\
\text { - retrospective } \\
\text { - info kept for } \\
\text { approx } 5 \text { years }\end{array}$ & $\begin{array}{l}\text { personal health } \\
\text { information } \\
\text { linked to } \\
\text { genotypes } \\
\text { - prospective } \\
\text { (approx } 30 \\
\text { years) }\end{array}$ & $\begin{array}{l}\text { personal health } \\
\text { information } \\
\text { linked to } \\
\text { genotypes and } \\
\text { genealogies } \\
\text { - retrospective \& } \\
\text { prospective } \\
\text { (approx } 5 \text { years) }\end{array}$ \\
\hline Size & $\begin{array}{l}\text { - } 270,000 \text { people } \\
\text { including } \\
\text { children and the } \\
\text { deceased } \\
\text { - whole population } \\
\text { of Iceland }\end{array}$ & $\begin{array}{l}1 \text { million people } \\
\text { including } \\
\text { children } \\
\text { - } 3 / 4 \text { of population } \\
\text { of Estonia }\end{array}$ & $\begin{array}{l}-500,000 \\
\text { unselected } \\
\text { adults aged 45- } \\
69 \text { years }\end{array}$ & $\begin{array}{l}\text { 60-65,000 } \\
\text { randomly } \\
\text { selected } \\
\text { individuals aged } \\
\text { 25-74 years }\end{array}$ \\
\hline Established by & $\begin{array}{l}\text { Iceland } \\
\text { government }\end{array}$ & $\begin{array}{ll}\text { - Estonian } \\
\text { government } \\
\text { - Estonian } \\
\text { Genome } \\
\text { Foundation }\end{array}$ & $\begin{array}{l}\text { - The Wellcome } \\
\text { Trust } \\
\text { - Medical } \\
\text { Research } \\
\text { Council } \\
\text { - UK } \\
\text { Department of } \\
\text { Health }\end{array}$ & $\begin{array}{l}\text { - Genome Quebec } \\
\text { - } \text { Quebec Network } \\
\text { of Applied } \\
\text { Genetic } \\
\text { Medicine } \\
\text { - } \\
\text { Ministère de la } \\
\text { recherche et de la } \\
\text { science et de } \\
\text { technologie } \\
\end{array}$ \\
\hline Oversight & $\begin{array}{l}\text { - Data Protection } \\
\text { Commission } \\
\text { - National } \\
\text { Bioethics } \\
\text { Committee } \\
\text { Dedicated bodies: } \\
\text { - monitoring } \\
\text { committee } \\
\text { - interdisciplinary } \\
\text { ethics committee }\end{array}$ & $\begin{array}{l}\text { - Ethics } \\
\text { Committee } \\
\text { - Estonian } \\
\text { Genome Project } \\
\text { Foundation (non- } \\
\text { profit } \\
\text { organisation } \\
\text { established by } \\
\text { Estonian } \\
\text { government) }\end{array}$ & $\begin{array}{l}\text { Proposed: } \\
\text { - centrally } \\
\text { managed with } \\
\text { project director } \\
\text { responsible to } \\
\text { funders } \\
\text { - separate, } \\
\text { independent } \\
\text { committee } \\
\text { responsible to } \\
\text { public, } \\
\text { research } \\
\text { participants } \\
\text { and other } \\
\text { stakeholders }\end{array}$ & $\begin{array}{l}\text { Public \& Social } \\
\text { Aspects: } \\
\text { - IPEG (Institute } \\
\text { advised by } \\
\text { independent } \\
\text { scientific \& } \\
\text { ethics boards) } \\
\text { Operation: } \\
\text { - scientific } \\
\text { steering } \\
\text { committee }\end{array}$ \\
\hline
\end{tabular}




\begin{tabular}{|c|c|c|c|c|}
\hline Operation & $\begin{array}{l}\text { - Research } \\
\text { resource with } \\
\text { exclusive license } \\
\text { to deCODE } \\
\text { Genetics } \\
\end{array}$ & $\begin{array}{l}\text { - public research } \\
\text { resource }\end{array}$ & 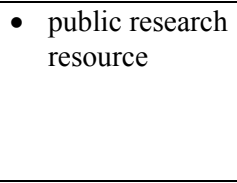 & $\begin{array}{l}\text { - public research } \\
\text { resource }\end{array}$ \\
\hline Access & $\begin{array}{l}\text { - } \text { Ministry of } \\
\text { Health } \\
\text { - by commercial } \\
\text { subscription }\end{array}$ & $\begin{array}{l}\text { - no exclusivity of } \\
\text { access } \\
\text { - access granted to } \\
\text { Estonian } \\
\text { Genome } \\
\text { Foundation } \\
\text { authorised } \\
\text { researchers \& } \\
\text { nonexclusive } \\
\text { licence } \\
\text { agreements with } \\
\text { pharmaceutical } \\
\text { \& biotech } \\
\text { companies via } \\
\text { EGeen (for-profit } \\
\text { subsidiary) }\end{array}$ & $\begin{array}{l}\text { no exclusivity } \\
\text { of access } \\
\text { - approval of } \\
\text { researchers by } \\
\text { funding } \\
\text { agencies' } \\
\text { mandates }\end{array}$ & $\begin{array}{l}\text { - no exclusivity of } \\
\text { access } \\
\text { - access granted to } \\
\text { CARTaGENE } \\
\text { authorised } \\
\text { researchers }\end{array}$ \\
\hline Confidentiality & $\begin{array}{l}\text { - } \text { personal } \\
\text { information } \\
\text { encrypted }\end{array}$ & $\begin{array}{l}\text { personal } \\
\text { information } \\
\text { encrypted }\end{array}$ & 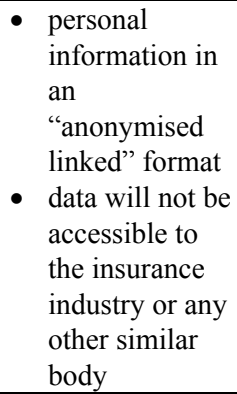 & $\begin{array}{ll}\text { - } & \text { personal } \\
\text { information } \\
\text { double-coded }\end{array}$ \\
\hline Consent & 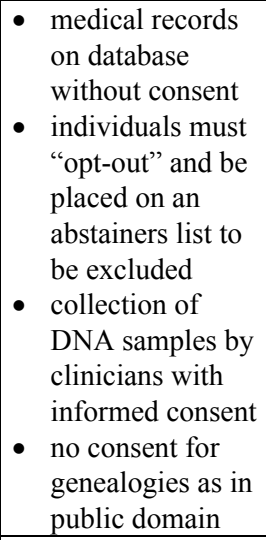 & $\begin{array}{l}\text { informed consent } \\
\text { (in writing) for } \\
\text { data and samples }\end{array}$ & 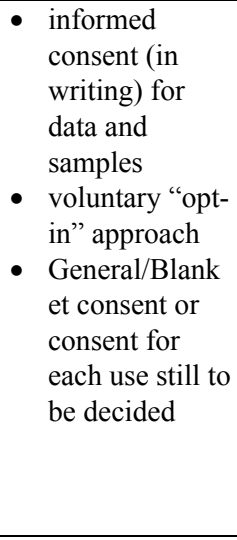 & $\begin{array}{l}\text { - } \text { informed consent } \\
\text { (in writing) for } \\
\text { data and samples } \\
\text { - voluntary "opt- } \\
\text { in" approach } \\
\text { - consent required } \\
\text { for each further } \\
\text { use }\end{array}$ \\
\hline Legislation & $\begin{array}{l}\text { specific } \\
\text { legislation: } \\
\text { Health Sector } \\
\text { Database Act } \\
1998\end{array}$ & $\begin{array}{l}\text { specific } \\
\text { legislation: } \\
\text { Human Genes } \\
\text { Research Act } \\
2000\end{array}$ & $\begin{array}{l}\text { no specific } \\
\text { legislation } \\
\text { covered by } \\
\text { Data } \\
\text { Protection Act } \\
\text { 1998, Human } \\
\text { Rights Act } \\
1998 \text { and } \\
\text { common law }\end{array}$ & $\begin{array}{ll}\text { no specific } \\
\text { legislation } \\
\text { covered by } Q C \\
\text { Civil Code \& } \\
\text { Acts under the } \\
\text { Personal } \\
\text { Information } \\
\text { Access } \\
\text { Commission }\end{array}$ \\
\hline
\end{tabular}


B. Godard, J. Marshall, C. Laberge and B.M. Knoppers

\section{REFERENCES}

1. Guttmacher A, Collins F.S. (2002) Genomic Medicine - A Primer. New England Journal of Medicine 347: 1512-20.

2. National Institutes of Health (NIH) (2002) Points to Consider When Planning a Genetic Study That Involves Members of Named Populations. (www.nih.gov/sigs/bioethics/named_populations.html).

3. Ivinson, A.J., Bach, F.H. (2002) The xenotransplantation question: Public consultation is an important part of the answer. Journal of American Medical College 167(1): 42-3.

4. Public Affairs and Communications Branch of Environment Canada (1994) Public Consultation Guideline $H-5$.

5. World Health Organization (WHO) (2002) Genomics and World Health, Report of the Advisory Committee on Health Research, Geneva (www3.who.int/whosis/genomics/pdf/genomics_report.pdf).

6. Mitchell, P. (2002) UK launches ambitious tissue/data bank project. Nature Biotechnology 20: 529.

7. Anon. (2002) Human genetic databases and the protection of medical information. Brief UK Policy Update (www.medinfo.cam.ac.uk/phgu/info_database/ELSI/genet-database.asp).

8. Kaye, J., Martin, P. (2000) Safeguards for research using large scale DNA collections. British Medical Journal 321: 1146-9.

9. Estonian Genome Foundation web site; (www.genomics.ee).

10. Annas, G. (2000) Rules for research on human genetic variation-lessons from Iceland. New England Journal of Medicine 342(24): 1830-33.

11. Godfrey, K. (2003) Genetic databank launches ethics framework. British Medical Journal 327: 700.

12. Deschenes, Cardinal, G. (2003) Projet CARTaGENE : Encadrement normatif. Centre de recherche en droit public, Universite de Montreal (www.cartagene.qc.ca).

13. Estonian Genome Project web site; (www.geenivaramu.ee).

14. Medical Research Council (MRC) (2001) Human tissue and biological samples for use in research: Operational and ethical guidelines (www.mrc.ac.uk/pdf-tissue_guide_fin.pdf).

15. Quebec Network of Applied Genetic Medicine (RMGA) (2000) Statement of Principles on Human Genome Research (www.rmga.qc.ca).

16. Quebec Network of Applied Genetic Medicine (RMGA) (2003) Statement of Principles on the Ethical Conduct of Human Genetic Research Involving Populations (www.rmga.qc.ca).

17. Commission de l'éthique de la science et de la technologie (2003) Avis les enjeux éthiques des banques d'information génétique: Pour un encadrement démocratique et responsible. Gouvernement du Quebec.

18. Gulcher, J., Stefansson, K. (2000) The Icelandic healthcare database and informed consent. New England Journal of Medicine 342: 1827-30.

19. Mannvernd web site; (www.mannvernd.is).

20. Overby, S. (2001) Iceland's dilemma: Privacy vs. progress. CIO Magazine (www.cio.com).

21. deCODE Genetics web site; (www.decode.com).

22. Sunsite: University of California at Berkeley; (http://sunsite.berkeley.edu/biotech/iceland/debate.html).

23. Human Genetics Commission (HGC) (2001) Public attitudes to human genetic information. (www.hgc.gov.uk).

24. Office of Science and Technology (OST), The Wellcome Trust (WT) (2000) Science and the public: A review of science communication and public attitudes to science in Britain. (www.wellcome.ac.uk/publications).

25. Cragg Ross Dawson (2000) Public perceptions of human biological samples. Report prepared for The Medical Research Council \& The Wellcome Trust (www.wellcome.ac.uk/en/1/biovenpopethpub.html).

26. Rawle, F.C., (2003) UK DNA sample collections for research. In: Populations and genetics: Legal and socio-ethical perspectives. ed. Knoppers, B.M., Kluwer Law International, The Hague/New York/London.

27. People Science \& Policy Ltd. (2002) UK Biobank: A question of trust. Report prepared for The Medical Research Council \& The Wellcome Trust (www.wellcome.ac.uk/en/1/biovenpopethtwo.html). 
28. UK Biobank web site; (www.biobank.ac.uk/consultation.htm).

29. McGrath, D. (2002) Ethical concerns at the DNA bank. Wired News (www.wired.com).

30. Gene Watch UK web site; (www.genewatch.org).

31. Human Genetics Alert web site; (www.hgalert.org).

32. Institute of Science in Society web site; (www.i-sis.org.uk).

33. CARTaGENE web site; (www.cartagene.qc.ca).

34. Condit, C. (2001) What is "public opinion” about genetics? Nature Reviews: Genetics 2: 811-15.

35. Breithaupt, H. (2001) The future of medicine. EMBO reports 2(6): 465-7.

36. Burton, B. (2002) Proposed genetic database on Tongans opposed. BMJ 324: 443.

37. Philipkoski, K. (2001) Framingham Gene Project Killed. Wired News (www.wirednews,com/news/Med-Tech/).

38. Juengst, E. (2000) What "community review" can and cannot do. The Journal of Law, Medicine \& Ethics 28(1): 52-4.

39. Resnik, D.B. (2001) Setting biomedical research priorities: Justice, science and public participation. Kennedy Institute of Ethics Journal 11(2): 181-204.

40. Furr, L.A. (2002) Perceptions of Genetics Research As Harmful to Society: Differences among Samples of African-Americans and European-Americans. Genetic Testing. 6: 25-30.

41. Dalton, R (2002) Tribe blasts ‘exploitation' of blood samples. Nature. 420: 111.

42. Burhansstipanov, L., Bemis, L.T., Dignan, M.B. (2001) Native American Cancer Education: Genetic and Cultural Issues. J. Cancer Ed. 16: 143.

43. Burgess, M. (YEAR??) Democracy, Ethics and Genomics : Consultation, Deliberation \& Modellings (http://gels.ethics.ubc.ca).

44. Foster, M.W., Sharp, R.R., Freeman, W.L., Chino, M., Bernsten, D., Carter, T.H. (1999) The role of community review in evaluating the risks of human genetic variation in research. American Journal of Human Genetics 64: 1719-27.

45. Weijer, C., Emanuel, E.J. (2000) Protecting communities in biomedical research. Science 289: 1142-4.

46. Jennings, B. (1990) Bioethics and Democracy. Centennial Review 34: 207-25.

47. Reiser S (1991) The Public and the Expert in Biomedical Policy Controversies. In: Hanna. Kathi E. (ed.), Biomedical Politics, National Academy Press, Washington, 325-31.

48. Harris Interactive (2001) The public is overwhelmingly optimistic and supportive of genomics research - however, knowledge and understanding remain modest. Health Care News.1: 20.

49. Weijer, C., Goldsand, G., Emanuel, E.J. (1999) Protecting communities in research: Current guidelines and limits of extrapolation. Nature Genetics 23(3): 275-80.

50. Caulfield, T., Outerbridge, T. (2002) DNA databanks, public opinion and the law. Med Clin Exp. 25: 255.

51. Furr, L.A. (1999) Social status and attitudes toward organizational control of genetic data. Sociolog. Focus 32: 371-382.

52. Holtzman, N.A. (1989) Proceed with Caution: Predicting Genetic Risks in the Recombinant DNA Era, Johns Hopkins University Press, Baltimore.

53. Shickle, D. (2001) A Matter of Opinion: New Methods of Public Consultation”. Wellcome Trust Magazine 29, Q4.

54. Habermas, J. (1992) De L'éthique de la discussion, Hunyadi, Flammarion.

55. Habermas, J. (1997) Droit et démocratie, Gallimard, Mayenne.

56. Health Canada (2000) Public Involvement: Framework \& Guidelines, Minister of Public Works and Government Services Canada, Ottawa.

57. Thibault, A., Lequin, M., et Tremblay, M. (2000) Cadre de référence de la participation publique (Démocratique, utile et crédible), Conseil de la santé et du bien-être Gouvernement du Québec, Sainte-Foy (Québec).

58. Goggin, M. (1986) Governing Science and Technology Democratically: A Conceptual Framework, in: Goggin, Malcolm L. (éd.) (1986): Governing Science and Technology in a Democracy, The University of Tennessee Press, Knoxville, pp. 3-31.

59. May, R. (2001) Science and Society. Science, 292: 1021. 